\title{
STRATEGI PENGEMBANGAN POTENSI EKOWISATA DI DESA MALATISUKA
}

\author{
Fauziah Hanum \\ Program Studi Magister Pemasaran Pariwisata Berkelanjutan \\ Sekolah Pascasarjana, Universitas Padjajaran \\ Email: fauziah19003@mail.unpad.ac.id

\section{Reiza D. Dienaputra} \\ Program Studi Magister Pemasaran Pariwisata Berkelanjutan \\ Sekolah Pascasarjana, Universitas Padjajaran \\ Email: reiza.dienaputra@unpad.ac.id \\ Dadang Suganda \\ Program Studi Magister Pemasaran Pariwisata Berkelanjutan \\ Sekolah Pascasarjana, Universitas Padjajaran \\ Email: dadang.suganda@unpad.ac.id

\section{Budi Muljana} \\ Program Studi Magister Pemasaran Pariwisata Berkelanjutan \\ Sekolah Pascasarjana, Universitas Padjajaran \\ Email: budi.muljana@unpad.ac.id
}

\begin{abstract}
ABSTRAK
Desa Malatisuka merupakan salah satu desa dengan kategori tertinggal di Kecamatan Gunung Tanjung, Kabupaten Tasikmalaya yang memiliki potensi alam dan lanskap berlimpah yang dapat dijadikan destinasi wisata unggulan apabila dikelola dengan baik dengan menerapkan konsep Ekowisata dan pengembangan mengacu pada prinsip berkelanjutan. Tujuan dari penelitian ini adalah untuk membuat strategi pengembangan potensi ekowisata di Desa Malatisuka, Kecamatan Gunung Tanjung, Kabupaten Tasikmalaya. Penelitian ini adalah studi kualitatif dengan metode survey dan deskriptif. Data untuk penelitian ini dikumpulkan melalui wawancara dengan teknik pemilihan narasumber menggunakan purposive sampling, studi literatur baik itu dari buku, procceding seminar, tesis, artikel-artikel jurnal dalam atau luar negeri serta sumber lainnya. Sedangkan data akan dianalisis menggunakan cara triangulasi serta analisis SWOT untuk selanjutnya melakukan perumusan strategi yang tepat untuk pengembangan potensi ekowisata tersebut. Hasil menunjukan bahwa Desa Malatisuk memiliki kelebihan dan peluang yang besar utamanya potensi alam yang apabila dimanfaatkan sebaik mungkin maka dapat menjadi nilai lebih yang menjadi
\end{abstract}


kekuatan untuk bersaing diantara daya tarik wisata khususnya dikembangkan untuk kegiatan ekowisata dan memungkinkan peluang untuk mengembangkan usaha kreatif lainnya dengan strategi yang telah dirumuskan berdasarkan analisis yang telah dilakukan.

Keywords: ekowisata, sustainable tourism, pengembangan wisata, air terjun

\section{Pendahuluan}

Ekowisata merupakan salah satu dari jenis kegiatan pariwisata yang mulai dipopulerkan pada tahun 1990-an. Sebagai salah satu negara kepulauan dengan biodiversitas yang kaya, Indonesia menjadi salah satu negara yang diuntungkan karena konsep pengembangan berbasis Konsep ekowisata bukanlah sebuah hal baru, dengan dinamisnya perubahan di dunia yang didukung oleh majunya teknologi ini ekowisata ini merupakan salah satu kegiatan alternatif terbaik bagi sebuah destinasi yang didukung oleh sumber daya alam melimpah seperti negara kita (Murianto, 2014). Konsep ekowisata ini muncul dari tuntutan yang mengarah pada pertanggungjawaban industry pariwisata bagi lingkungan hidup terhadap pengelolaan destinasi (Samsuhardjo, Margono \& Purbokusumo, n.d). Ekowisata menjadi perpaduan dari berbagai faktor yang tumbuh dari keprihatinan terhadap isuisu lingkungan, ekonomi dan sosial. Kegiatan ekowisata ini bertujuan untuk meminimalkan dampak, menumbuhkan kesadaraan lingkungan dan budaya, memberikan pengalaman positif baik kepada turis (visitors) maupun penerima (host) dan memberikan manfaat dan keberdayaan masyarakat lokal (Samsuhardjo, Margono \& Purbokusumo, n.d).

Desa Malatisuka merupakan desa pemekaran dari Desa Bengkok Kecamatan Salopa. Ltak geografis desa Malatisuka terdiri dari lahan yang berupa daratan dan sebagian besar digunakan untuk area perkebunan yaitu sekitar 2.500 Ha. Sebagian besar dari area perkebunan Desa Malatisuka merupakan potensi alam. Potensi alamnya yaitu terdiri dari perkebunan kapolaga dan penghasil gula aren. Mayoritas 
penduduk bekerja sebagai petani dan buruh dengan rata-rata tingkat pendidikan hanya sampai SMP/SMA (Kecamatan Gunung Tanjung dalam Angka, 2019).

Ada beberapa permasalahan yang menjadi faktor utama kurang berkembangnya desa dan kesejahteraan masyarakat ini menurut Bapak Asep Yosep Hermawan selaku Kepala Desa Malatisuka, diantaranya yaitu status desa yang tertinggal, tingkat pendidikan - kesejahteraan masyarakat yang rendah, kurangnya dukungan pada sarana dan prasarana (Sergap, 2019). Desa Malatisuka merupakan salah satu desa di Kabupaten Tasikmalaya yang masih termasuk dalam kategori tertinggal dengan nilai IDM 0,556 dengan presentase indeks komposit ekonomi dan lingkungan yang tergolong rendah yaitu 29,9 (IKS) dan 27,96\% (IKL) (Data Kemendes, 2020).

Sebagian besar masyarakat di Desa Malatisuka ini hanya mengenyam pendidikan hingga tingkat SMP atau SMA saja. Selain itu untuk profesi pekerjaan, mayoritas masyarakat merupakan petani dan buruh, sehingga tingkat ekonomi dapat dikatakan dalam kategori rendah. Selain itu, di Desa Malatisuka ini belum banyak sarana dan prasarana publik yang tersedia yang menunjang kesejahteraan masyarakat dan kegiatan perekonomian (akses distribusi logistik). Akesibilitas juga masih banyak yang perlu untuk diperbaiki terutama menuju destinasi karena masih belum baik.

Hal ini sangat disayangkan sekali padahal Desa Malatisuka mempunyai potensi alam lanskap yang berlimpah yaitu lanskap kebun, pertanian, pegunungan dan vegetasi pohon salak. Dilihat dari potensinya Desa Malatisuka ini memiliki sumber daya alam berlimpah namun masih belum dikelola dengan optimal yaitu berupa sawah, hutan dan perkebunan (kapulaga, aren, salak). Permasalahan ini dapat diatasi salah satunya dengan cara membuat perencanaan strategi pengembangan pariwisata berkelanjutan yang disintesiskan dengan konsep ekowisata. Dengan diterapkannya kegiatan ekowisata, konservasi keanekaragaman hayati dapat tetap 
terjaga karena aktifitas terdukung dan juga ramah lingkungan disamping itu dapat membantu meningkatkan kesejahteraan penduduk setempat (Ziku, 2015).

\section{Tinjauan Pustaka}

\section{Ekowisata}

Ekowisata merupakan kegiatan wisata berbasis alam yang berkelanjutan dengan yang menjadi fokus utama adalah pengelolaan dengan pemahaman terhadap alam (Suryajaya \& Adikampana, 2019). Ekowisata ini merupakan bentuk atau konsep wisata minat khusus karena dapat dikatakan sebagai lawan dari wisata massal atau konvensional (Aliman, 2017). Dalam pengelolaan ekowisata ini alam dan lingkungannya menjadi sumber daya utama yang harus diatur dengan hati-hati (tidak bersifat konsumtif dan terkontrol) agar kebermanfaatannnya tetap terjaga (Suryajaya \& Adikampana, 2019).

Elemen atau karakteristik yang membangun ekowisata yang telah banyak dipakai dan disetujui yaitu nature (daya tarik wisata berbasis alam yang berfokus pada ekosistem yang masih asli), education (adanya hal yang bisa diambil atau dipelajari) dan sustainable (adanya perencanaan dan manajemen untuk mewujudkan keberlanjutan) (Jamil \& Waluya, 2016). Adapula yang berpendapat bahwa dimensi dari ekowisata ini adalah ekologi (partisipasi aktif dari komponen utama dalam menjaga kelestarian sumber daya alam), ekonomi (keuntungan yang dirasakan oleh masyarakat karena adanya aktifitas ekowisata yang dilakukan utamanya bagi kelestarian sumber daya itu sendiri) serta dimensi sosial (selain berperan aktif,, masyarakat memiliki wewenang untuk ikut mengelola dan mengawasi). Pengembangan ekowisata di Indonesia sendiri telah diatur dan ditetapkan oleh pemerintah pusat dengan diterbitkannya Peraturan Menteri Dalam Negeri Nomor 33 tahun 2009 tentang Pedoman Pengembangan Ekowisata di Daerah. Pedoman 
Fauziah Hanum, Reiza D. Dienaputra, Dadang Suganda, Budi Muljana

tersebut berisi tentang prinsip-prinsip pengembangan ekowisata di daerah (Samsuhardjo, Margono \& Purbokusumo, n.d).

Pada umumnya produk dari ekowisata ini meliputi adanya potensi, daya tarik, fasilitas dan aksesibilitas (Suryajaya \& Adikampana, 2019). Penerapan konsep ekowisata ini biasanya dilakukan pada daerah dengan sumber daya alam melimpah atau lanskap yang kaya seperti desa-desa atau daerah pinggiran. Pengimplementasian konsep ekowisata berfokus pada bagaimana pengelolaan sebuah objek sebaik mungkin dan pemberian edukasi atau pemahaman agar tidak terjadinya kerusakan atau pencemaran baik itu pada aspek lingkungan, sosial maupun budaya setempat. Pada pengembangannya pelibatan dan partisipasi masyarakat merupakan salah satu kunci dari keberhasilan kegiatan ekowisata ini (Ziku, 2015).

\section{Unsur-Unsur Pengembangan Pariwisata}

Kajian mengenai pengembangan destinasi pada saat ini pada umumnya mengikuti konsep dasar yang diinisiasi oleh Medlik pada tahun 1980 dan diangkat oleh Cooper pada tahun 1993. Copper menyebutkan bahwa ada 4 komponen destinasi wisata yang perlu dipahami sebelum melakukan penyusunan strategi bagi destinasi. Unsur-unsur dalam pengembangan pariwisata tersebut adalah:

1. Attraction (Atraksi) yaitu segala keindahan, keunikan alam, budaya setempat, peninggalan bersejarah dan daya tarik buatan yang menjadi produk utama dari sebuah destinasi. Atraksi pada sebuah destinasi ini sebaiknya mencakup tiga aspek yaitu hal yang bisa dilakukan (what to do), hal yang bisa dilihat (what to see) dan hal yang dapat dibeli atau menjadi kenang-kenangan (what to buy).

2. Accessibility (Aksesibilitas) yaitu seluruh sarana dan infrastruktur yang diperlukan baik sebelum hingga sampai dan berada di sebuah destinasi. Misalnya akses jalan raya, ketersediaan sarana transportasi serta rambu-rambu petunjuk. 
3. Amenities (Amenitas) yaitu tersedianya fasilitas dasar yang menjadi keperluan dasar dari destinasi tersebut. Misalnya ketersediaan jalan, transportasi, akomodasi, informasi, penyedia jasa dan lainnya.

4. Ancillary yaitu fasilitas-fasilitas yang mendukung dari fasilitas dasar. Misalnya adanya organisasi atau badan pengelola destinasi, partner kerjasama dan lainnya.

\section{Prinsip Pengembangan Ekowisata}

Dalam mengembangan ekowisata ada tiga prinsip dasar yang harus ditekankan yaitu sebagai berikut (Samsuharjo, Margono \& Purbokusumo, n.d):

1. Prinsip konservasi, yaitu pengembangan ekowisata harus mampu memelihara, melindungi, dan berkontribusi untuk memperbaiki sumberdaya alam.

2. Prinsip partisipasi masyarakat yaitu pengembangan harus didasarkan atas musyawarah masyarakat setempat serta peka dan menghormati nilai-nilai sosial budaya dan keragaman tradisi yang dianut masyarakat sekitar kawasan.

3. Prinsip ekonomi yaitu pengembangan ekowisata harus mampu memberikan manfaat bagi masyarakat setempat dan menjadi penggerak pembangunan ekonomi agar dapat mengembangkan pembangunan yang berimbang.

\section{Strategi Pengembangan Pariwisata}

Selain dari unsur-unsur dasar dalam pengembangan pariwisata tersebut, karakteristik dari destinasi itu sendiri tentulah menjadi faktor penting yang menjadikan strategi pengembangan untuk tiap destinasi itu menjadi berbeda sesuai dengan kebutuhan dan kondisi dari destinasi tersebut. Perlu dilakukannya analisis SWOT untuk mengetahui terlebih dahulu kelebihan, kekurangan, peluang dan tantangan dari destinasi tersebut tidak bisa melakukan perumusan strategi 
pengembangan secara tiba-tiba, harus adanya proses identifikasi potensi terlebih dahulu.

Konsep dan unsur-unsur pengembangan yang sudah ada hingga saat ini masih dapat digunakan karena masih relevan dengan keadaan lapangan. Sehingga untuk pembaruan belum begitu diperlukan namun karena cakupan pariwisata yang luas maka perlu adanya sebuah model atau kerangka berfikir yang disusun dengan mempertimbangkan aspek-aspek lain yang berelasi. Selain itu dalam melakukan penyusunan strategi pengembangan khususnya destinasi, keberlanjutan tentulah harus menjadi salah satu concern utama. Aspek keberlanjutan tersebut adalah sebagai berikut:

\section{Sosial}

Pengembangan sebuah destinasi haruslah membawa kebermanfaatan pada masyarakat dan lingkungan sosial. Pengembangan yang dilakukan haruslah dapat membuka peluang bagi masyarakat untuk ikut berkembang (terbukanya peluang usaha dan lapangan pekerjaan serta meningkatkan kesejahteraan sosial) tanpa menyebabkan konflik.

\section{Lingkungan}

Segala pemanfaatan, pembangunan dan pengembangan yang dilakukan untuk kegiatan pariwisata khususnya destinasi tidak merusak ekosistem lingkungan yang ada. Sumber daya khususnya alam yang ada harus tetap terjaga ketersediaan dan kelestariannya sebagai dasar agar dapat tetap ada.

\section{Budaya}

Pengembangan yang dilakukan tidak merubah kebiasaan atau kebudayaan asli yang ada di sekitar destinasi tersebut malah semakin memperkaya dan mendukung kemajuan dari kebudayaan tersebut menjadi usaha kreatif atau budaya yang lestari. 


\section{Metode Penelitian}

Penelitian ini adalah studi kualitatif dengan metode survey dan deskriptif. Data untuk penelitian ini dikumpulkan melalui observasi langsung ke objek, studi literatur baik itu dari buku, procceding seminar, tesis, artikel-artikel jurnal dalam atau luar negeri serta sumber lainnya dan. Wawancara ini berfungsi untuk menggali informasi lebih lanjut yang akan digunakan dalam membantu perumusan startegi pengembangan yang sesuai, cara yang dilakukan untuk wawancara ini yaitu menggunakan teknik pusposive sampling dengan kriteria narasumber sebagai berikut:

1. Narasumber merupakan warga asli yang berasal dan berdomisili di Desa Malatisuka

2. Narasumber merupakan perwakilan atau dapat menajdi representatif dari unsur pentahelix untuk kebutuhan informasi mengenai usaha pengembangan yang sudah dilakukan.

3. Narasumber berinteraksi atau terlibat langsung dengan kegiatan atau usahausaha dan pelaku pariwisata yang ada di Desa Malatisuka.

Untuk teknik analisis data, setelah tahap pengumpulan data maka penulis akan menganalisis data menggunakan cara triangulasi, selanjutnya dilakukan identifikasi potensi serta analisis SWOT untuk mengetahui posisi dari potensi desa ini serta selanjutnya melakukan perumusan strategi yang tepat untuk pengembangan potensi ekowisata di Desa Malatisuka, Kecamatan Gunung Tanjung, Kabupaten Tasikmalaya.

\section{Hasil dan Pembahasan}

\section{Profil Desa Malatisuka, Kecamatan Gunung Tanjung, Kabupaten Tasikmalaya}

Desa Malatisuka merupakan desa pemekaran dari Desa Bengkok Kecamatan Salopa. Letak geografis dari Desa Malatisuka terdiri dari lahan yang berupa daratan dan sebagian besar digunakan untuk area perkebunan yaitu sekitar 2.500 Ha. 
Sebagian besar dari area perkebunan Desa Malatisuka merupakan potensi alam. Potensi alamnya yaitu terdiri dari perkebunan kapolaga dan penghasil gula aren. Mayoritas penduduk bekerja sebagai petani dan buruh dengan rata-rata tingkat pendidikan hanya sampai SMP/SMA (Kecamatan Gunung Tanjung dalam Angka, 2019).

\section{Identifikasi Potensi Wisata di Desa Malatisuka, Kecamatan Gunung Tanjung, Kabupaten Tasikmalaya}

Desa Malatisuka memiliki beberapa potensi yang dapat dikembangkan untuk kegiatan wisata khususnya ekowisata. Potensi utama yang dimiliki oleh Desa Malatisuka ini sebagian besar berupa potensi wisata alam namun tidak menutup kemungkinan akan munculnya wisata buatan dan budaya untuk kedepannya. Berikut adalah rincian mengenai potensi dan peluang pengembangan wisata untuk Desa Malatisuka:

1. Atraksi

- Lanskap

Desa Malatisuka mempunyai potensi alam lanskap yang berlimpah yaitu lanskap kebun, pertanian, pegunungan dan vegetasi pohon salak.

- Sumber Daya Alam

Desa Malatisuka ini memiliki potensi sumber daya alam berlimpah namun masih belum dikelola dengan optimal yaitu berupa sawah, hutan dan perkebunan (kapulaga, aren, salak). Selain itu juga Desa Malatisuka memiliki sumber daya air yang melimpah dengan pusat di Curug Cipanaha.

\section{Aksesibilitas}

Desa Malatisuka dapat diakses menggunakan kendaraan pribadi dengan jarak tempuh sekitar 90 menit dari Pusat Pemerintahan Kabupaten Tasikmalaya dan 30 menit dari Pusat Pemerintahan Kota Tasikmalaya. Selain itu juga dapat diakses 
menggunakan kendaraan umum (berupa bis dan elf) dengan trayek Bandung Pangandaran via Manonjaya.

\section{Amenitas}

Desa Malatisuka belum memiliki fasilitas terstandar yang menunjang untuk kegiatan pariwisata. Di lokasi destinasi wisata sendiri (Curug Cipanaha) belum tersedianya fasilitas dasar yang memadai. Belum adanya kantor pengelola serta pusat informasi untuk menunjang kegiatan operasional di lokasi, belum adanya fasilitas mandi - cuci - kakus yang permanen hanya ada bilik yang dibuat secara sederhana. Loket tiket resmi dan lapang parkir juga tidak ada walaupun ada oknum yang memungut biaya untuk kedua hal tersebut.

Disamping hal mendasar yang seharusnya ada di destinasi, belum adanya akomodasi khusus untuk wisatawan di destinasi wisata yang ada, rumah makan yang tersedia di sepanjang jalan menuju destinasi wisata juga umumnya berukuran kecil dan hanya untuk memenuhi kebutuhan masyaraka sekitar saja tidak secara khusus dibuat untuk menunjang kegiatan pariwisata, tidak ada toko cindramata ataupun biro perjalanan serta penukaran uang dan fasilitas penunjang kenyamanan wisatawan lainnya.

\section{Ancilary Service}

Tidak banyak sarana dan prasarana publik yang tersedia di Desa Malatisuka untuk menunjang kesejahteraan masyarakat seperti rumah sakit, bank ataupun kantor pos. Hal tersebut harus diakses di daerah sekitar Pemerintah Daerah Kabupaten Tasikmalaya (Desa Manonjaya) atau menginduk ke Kota Tasikmalaya. Selain itu akses dan sarana distribusi logistik untuk menunjang kegiatan perekonomian juga masih belum banyak dan dikelola dengan baik. 


\section{Potensi Penerapan dan Pengelolaan Kegiatan Ekowisata di Desa Malatisuka}

Melihat dari potensi yang ada, Desa Malatisuka ini berpotensi untuk dikembangkan sebagai salah satu destinasi Ekowisata. Berikut adalah rincian mengenai potensi dan peluang pengembangannya berdasarkan elemen dari Ekowisata:

- Nature:

Curug Cipanaha dapat menjadi percontohan destinasi ekowisata pertama Desa Malatisuka karena selain ekosistemnya termasuk kategori masih asli selain itu didukung juga dengan lanskap dan sumber daya lainnya yang mendukung.

\section{- Education:}

Ada beberapa hal yang dapat dijadikan sebagai daya tarik wisata edukasi ataupun sarana pembelajaran dan percontohan yang dapat mengangkat tingkat perekonomian masyarakat sekitar yaitu dengan pembentukan dan pelibatan UMKM di Desa Malatisuka ini dengan produk yang menjadi unggulan yaitu budidaya dan serba-serbi olahan dari tanaman salak, kapulaga, kelapa, padi serta hasil kebun lainnya.

\section{- Sustainable:}

Status dan kondisi desa yang termasuk dalam kategori tertinggal menjadikan Desa Malatisuka ini cocok dan terbuka untuk dapat dirancang, dibentuk, ditata, dikelola dan dikembangkan sesuai dengan prinsip keberlanjutan untuk mewujudkan tercapainya kesejahteraan bersama dan lestarinya lingkungan yang dapat dinikmati hingga generasi selanjutnya. 
Strategi Pengembangan Potensi Ekowisata di Desa Malatisuka, Kecamatan Gunung Tanjung, Kabupaten Tasikmalaya

\section{Identifikasi Potensi Pengembangan Ekowisata Desa Margacinta}

Salah satu tahapan dalam pembuatan sebuah strategi pengembangan adalah melakukan identifikasi kekuatan, kelemahan, peluang dan tantangan dari objek tersebut agar dapat diketahui hal mana saja yang perlu mendapat perhatian lebih lanjut. Berikut terlampir pada Tabel 1 hasil analisis SWOT pengembangan potensi ekowisata di Desa Malatisuka.

Tabel 1. Analisis SWOT Potensi Wisata dan Pengembangan Ekowisata di Desa Malatisuka

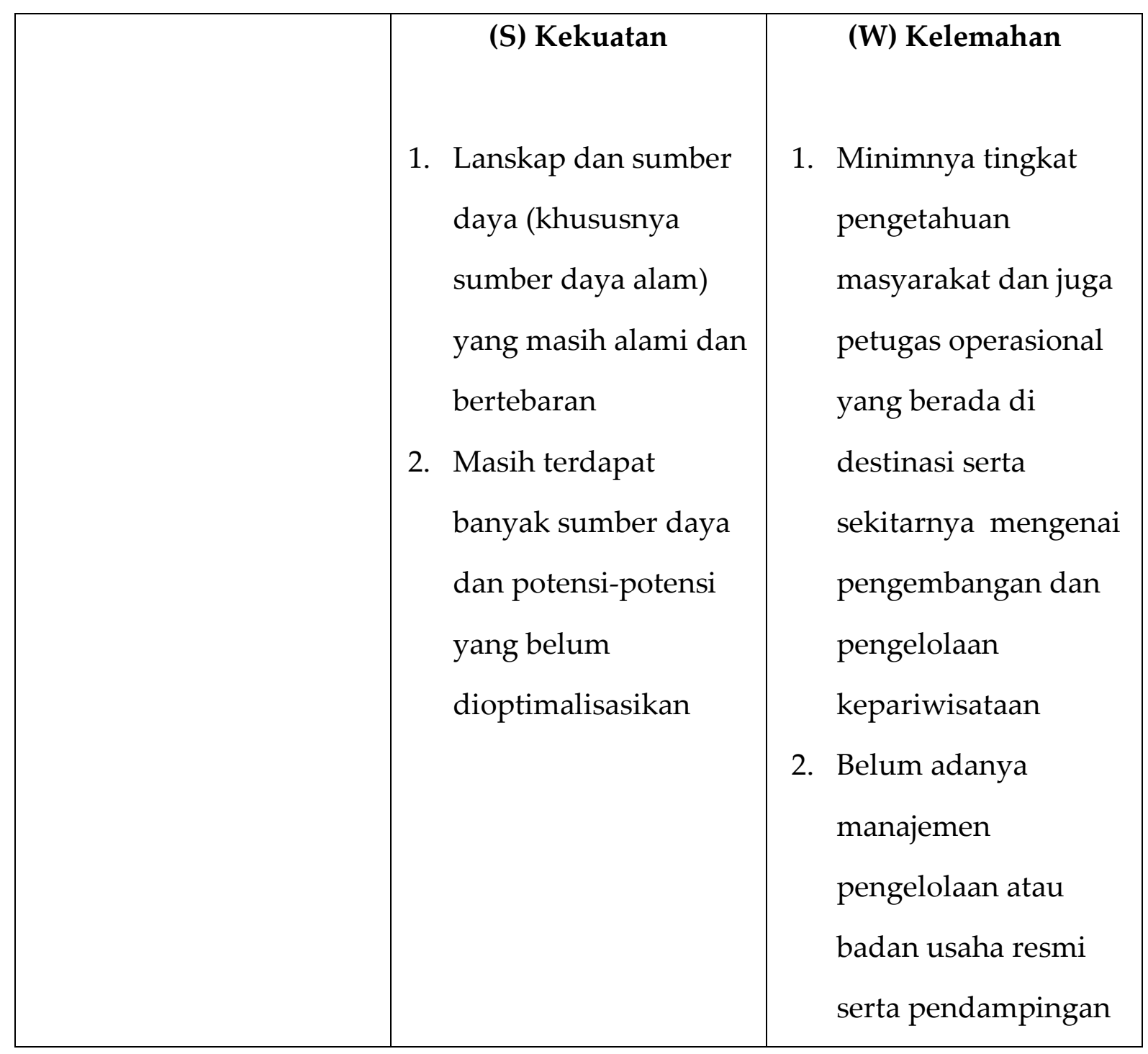




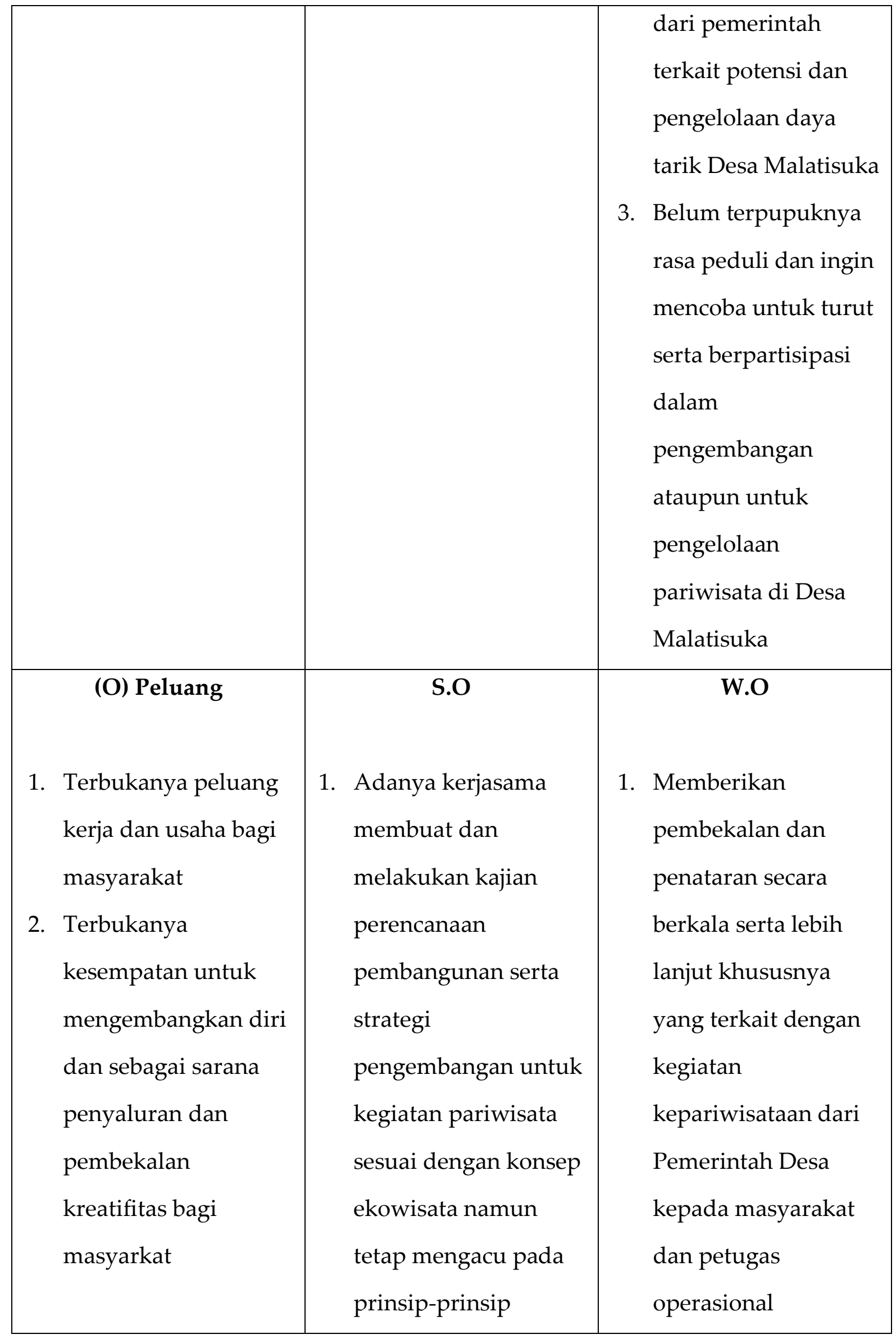




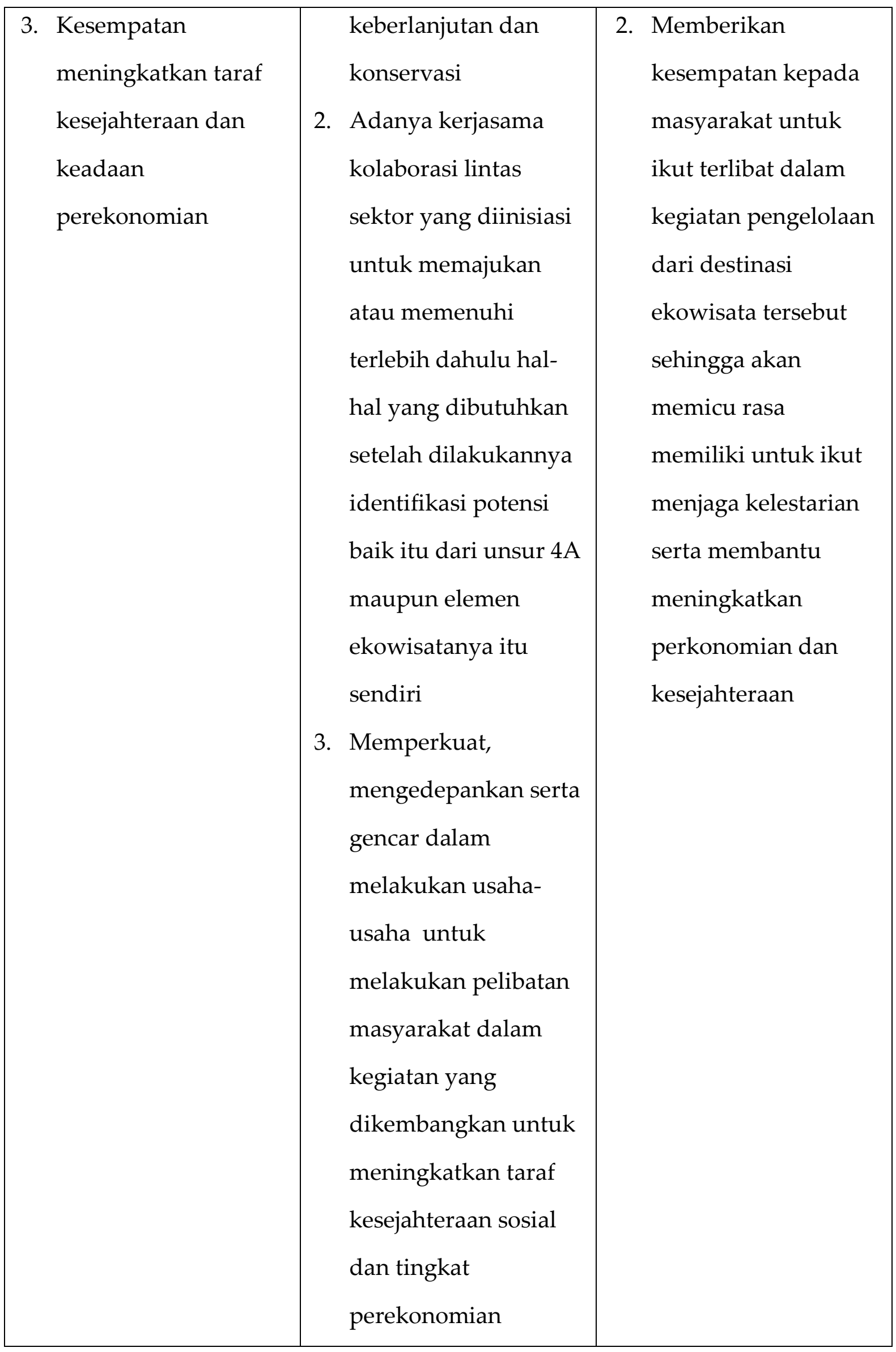




\begin{tabular}{|c|c|c|}
\hline (T) Tantangan & S.T & W.T \\
\hline $\begin{array}{l}\text { 1. Adanya kegiatan } \\
\text { wisata yang serupa } \\
\text { serta pengelolaan dan } \\
\text { produk yang lebih } \\
\text { baik dari daerah } \\
\text { sekitar } \\
\text { 2. Pesatnya kemajuan } \\
\text { teknologi dan } \\
\text { informasi yang tidak } \\
\text { dimanfaatkan dengan } \\
\text { baik dapat membuat } \\
\text { kalah bersaing }\end{array}$ & $\begin{array}{l}\text { 1. Melakukan banyak } \\
\text { inovasi } \\
\text { 2. Meningkatkan, } \\
\text { memperkuat serta } \\
\text { memberikan } \\
\text { informasi terkait } \\
\text { dengan potensi yang } \\
\text { ada secara masif } \\
\text { (brand awarness) agar } \\
\text { eksistensi Desa } \\
\text { Malatisuka dapat } \\
\text { diketahui terlebih } \\
\text { dahulu sebelum } \\
\text { dilakukan strategi } \\
\text { lainnya } \\
\text { Memberi pelatihan- } \\
\text { pelatihan baik } \\
\text { keterampilan yang } \\
\text { menunjang } \\
\text { kegiatan ekowisata ini }\end{array}$ & $\begin{array}{l}\text { 1. Memperkuat } \\
\text { pengetahuan produk } \\
\text { dan kompetensi baik } \\
\text { pengelola, pelaku } \\
\text { wisata dan } \\
\text { masyarakat terkait } \\
\text { agar mampu bersaing }\end{array}$ \\
\hline
\end{tabular}


Tabel 2. Matriks Internal Potensi Wisata dan Pengembangan Ekowisata di Desa Malatisuka (IFAS)

\begin{tabular}{llllc}
\hline \multicolumn{1}{c}{ Faktor Strategis Internal } & Rating & Bobot & Skor \\
\hline Kekuatan & & & \\
\hline $1 \quad$ Lanskap dan sumber daya yang masih alami & 4,5 & 0,5 & 2,25 \\
\hline $2 \quad \begin{array}{l}\text { Masih terdapat banyak sumber daya dan } \\
\text { potensi-potensi yang belum dioptimalisasikan }\end{array}$ & 5.0 & 0,5 & 2,50 \\
\hline Total & $\mathbf{1}$ & $\mathbf{4 , 7 5}$ \\
\hline
\end{tabular}

\section{Kelemahan}

Minimnya tingkat pengetahuan masyarakat dan juga petugas operasional yang berada di

1 destinasi serta sekitarnya mengenai $3,0 \quad 0,3 \quad 0,9$ pengembangan dan pengelolaan kepariwisataan Belum adanya manajemen pengelolaan atau badan usaha resmi serta pendampingan dari pemerintah terkait potensi dan pengelolaan

$3,5 \quad 0,3 \quad 1,05$
daya tarik Desa Malatisuka

Belum terpupuknya rasa peduli dan ingin mencoba untuk turut serta berpartisipasi dalam pengembangan ataupun untuk pengelolaan

$2,5 \quad 0,3 \quad 0,75$
pariwisata di Desa Malatisuka

\begin{tabular}{cccc}
\hline Total & 1 & 2,70 \\
\hline Selisih & & 2.05 \\
\hline
\end{tabular}


Tabel 3. Matriks Eksternal Potensi Wisata dan Pengembangan Ekowisata di Desa Malatisuka (EFAS)

\begin{tabular}{|c|c|c|c|c|}
\hline \multicolumn{2}{|r|}{ Faktor Strategis Internal } & Rating & Bobot & Skor \\
\hline \multicolumn{5}{|c|}{ Peluang } \\
\hline 1 & $\begin{array}{l}\text { Terbukanya peluang kerja dan usaha bagi } \\
\text { masyarakat }\end{array}$ & 4,5 & 0,3 & 1,35 \\
\hline 2 & $\begin{array}{l}\text { Terbukanya kesempatan untuk } \\
\text { mengembangkan diri dan sebagai sarana } \\
\text { penyaluran dan pembekalan kreatifitas bagi } \\
\text { masyarkat }\end{array}$ & 5,0 & 0,3 & 1,50 \\
\hline 3 & $\begin{array}{l}\text { Kesempatan meningkatkan taraf kesejahteraan } \\
\text { dan keadaan perekonomian }\end{array}$ & 4,25 & 0,3 & 1,28 \\
\hline & Total & & 1 & 4.13 \\
\hline
\end{tabular}

\section{Ancaman}

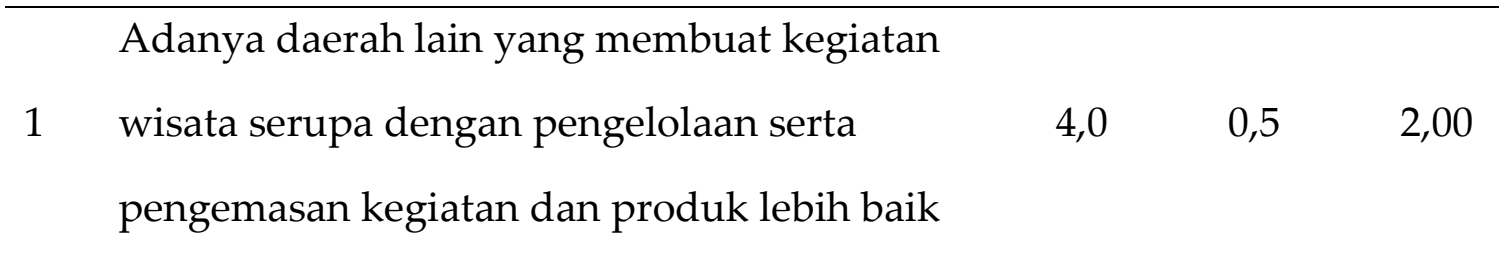

Pesatnya kemajuan teknologi dan informasi

2 yang tidak dimanfaatkan dengan baik akan $\quad 4,5 \quad 0,5 \quad 2,25$ membuat Desa Margacinta kalah bersaing

\begin{tabular}{cccc}
\hline Total & 1 & 4,25 \\
\hline Selisih & & $-0,12$ \\
\hline
\end{tabular}


Tabel 4. Rekapitulasi Hasil Skor IFAS dan EFAS Analisis SWOT Potensi Wisata dan Pengembangan Ekowisata di Desa Malatisuka

\begin{tabular}{cc}
\hline \multicolumn{2}{c}{ Total Skor } \\
\hline IFAS & 2.05 \\
\hline EFAS & $-0,12$ \\
\hline
\end{tabular}

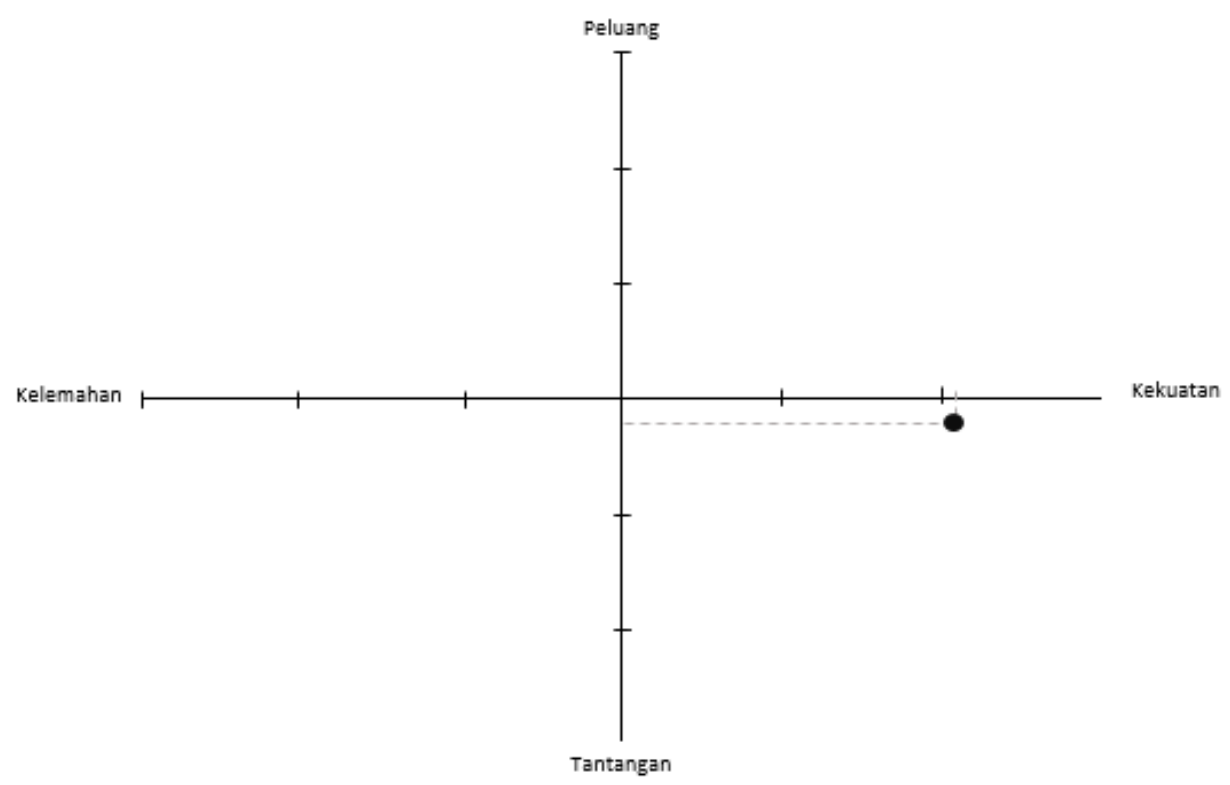

Gambar 1. Diagram Kartesius Analisis SWOT Potensi Wisata dan Pengembangan Ekowisata di Desa Malatisuka

Dari gambar 1. Diagram Kartesius Analisis SWOT Potensi Wisata dan Pengembangan Ekowisata di Desa Malatisuka diatas terlihat bahwa posisi pelaksanaan kegiatan ekowisata Desa Malatisuka ini berada pada kuadran IV artinya meskipun masih banyak hal yang kurang dan harus ditingkatkan karena selain menghadapi ancaman dari luar terdapat pula kelemahan internal, namun Desa Malatisuka masih memiliki kelebihan dan peluang yang besar apabila dimanfaatkan dengan benar maka dapat menjadi nilai lebih untuk bersaing. 
Rekomendasi strategi pengembangan yang perlu untuk difokuskan adalah strategi diversifikasi. Perlu adanya program-program peragaman pengelolaan dan berbagai usaha kreatif lainnya baik itu dari aspek destinasi, pemasaran dan industri yang terkait dalam kegiatan ekowisata di lingkungan Desa Malatisuka ini di dukung dengan peran dukungan dan dorongan dari kelembagaan (daerah dan pusat) sehingga lambat laun akan adanya perubahan dan kemajuan pesat sesuai dengan yang diharapkan.

\section{Program Pengembangan Potensi Ekowisata di Desa Malatisuka}

Berikut adalah beberapa rekomendasi untuk pengembangan yang dapat dilakukan terkait kegiatan Ekowisata di Desa Malatisuka dengan memperhatikan prinsip-prinsip berkelanjutan dan prinsip dasar ekowisata:

\section{Program pengembangan Destinasi}

- Arah dan konsep pengembangan daya tarik wisata lebih mengedepankan kepada pemanfaatan alam sesuai dengan konsep berkelanjutan dan aspekaspek pengembangan wisata dengan tak lupa membina dan melakukan pelibatan masyarakat dalam kegiatannya.

- Menjalin kerjasama dengan Perhutani sebagai pemilik (sebagian lahan) dan pengelola tempat-tempat yang dapat dikembangkan untuk kegiatan ekowisata, contohnya daerah Curug Cipanaha dan hutan disekitarnya.

- Memperkuat pemberian pengetahuan produk dan kompetensi baik untuk pengelola, pelaku wisata dan masyarakat yang terlibat dalam lingkungan usaha kegiatan pengembangan ekowisata di Desa Malatisuka agar mampu bersaing.

- Perbaikan dan pembangunan sarana dan prasarana penunjang yang kondisinya kurang baik atau belum tersedia misalnya balai berkumpul atau kantor pengelola dan informasi center. 
- Pengembangan inovasi potensi wisata lainnya berdasarkan potensi yang sudah diidentifikasi dan produk-produk kreatif yang berdasarkan pada pemanfaatan sumber daya alam dan kekayaan sumber daya pertanian yang ada di sekitar Curug Cipanaha.

2. Program pengembangan Pemasaran

Melakukan beberapa cara pemasaran dengan memanfaatkan kemajuan perkembangan teknologi, informasi dan komunikasi sebagai berikut agar brand awarness dan eksistensi Desa Malatisuka khususnya Curug Cipanaha semakin terdengar:

- Berkerjasama dengan Dinas Pemuda, Olahraga dan Pariwisata Kabupaten juga dapat berkerja sama dengan Kota Tasikmalaya untuk melakukan kegiatan pengenalan adanya potensi untuk Ekowisata di Desa Malatisuka.

- Digital marketing:

Membuat website atau blog yang dikelola sendiri, lebih aktif dalam menggunakan sosial media untuk pengkomunikasian produk dan kegiatan ekowisata yang ada di Desa Malatisuka.

3. Program pengembangan Industri

- Adanya peran aktif dari perangkat Desa untuk membantu memperbaiki dan meningkatkan kesadaran masyarakat terhadap pentingnya mendukung kemajuan program pengembangan ekowisata yang sedang diupayakan.

- Melakukan diskusi dan kolaborasi bersama dengan industri-industri terkait lainnya di tingkat Kabupaten atau Kota agar mendapatkan ide-ide baru dan saling mendukung.

- Membuka peluang kerjasama dengan pelaku industri lainnya dari luar Kabupaten Tasikmalaya dan sekitarnya (Kota Tasikmalaya dan Kota Ciamis). 
4. Program pengembangan Kelembagaan

- Adanya wadah yang menyatukan untuk berbagi aspirasi

- Kolaborasi dan bersinergi dengan pemerintah untuk pengkomunikasian, pemasaran dan pengembangan ekowisata khususnya daerah sekitar Curug Cipanaha di Desa Malatisuka.

\section{Kesimpulan dan Saran}

\section{Kesimpulan}

Berdasarkan hasil kajian yang dilaksanakan mengenai Ekowisata di Desa Malatisuka ini maka dapat diambil kesimpulan sebagai berikut :

1. Dapat diketahui bahwa potensi wisata di Desa Malatisuka yaitu potensi untuk wisata alam dan wisata kreatif dengan nilai keunggulan pada potensi alam (lanskap) dan kerajinan atau usaha keatif.

2. Penerapan kegiatan ekowisata di Desa Malatisuka termasuk pada kategori cukup, masih terdapat hal-hal yang harus ditingkatkan kembali agar dapat mencapai tujuan menjadi destinasi ekowisata unggulan Kabupaten Tasikmalaya.

3. Berdasarkan analisis yang telah dilakukan, kegiatan ekowisata di Desa Malatisuka berada pada kuadran II yang artinya meskipun menghadapi banyak ancaman dari luar terdapat pula kelemahan internal, namun Desa Malatisuka masih memiliki kelebihan dan peluang yang besar apabila dimanfaatkan sebaik mungkin maka dapat menjadi nilai lebih yang menjadi kekuatan untuk bersaing diantara daya tarik wisata khususnya untuk ekowisata dan mengembangkan usaha kreatif lainnya. 
Saran

Berdasarkan hasil penelitian yang telah dilaksanakan terdapat beberapa saran yang dapat dilakukan sebagai salah satu upaya untuk meningkatkan Pariwisata Kreatif di Desa Margacinta sebagai berikut :

1. Potensi wisata yang sudah di identifikasi sebaiknya dimanfaatkan sebaik mungkin dengan selalu melibatkan prinsip keberlanjutan dalam pemutusan rencana karena merupakan nilai lebih yang menjadi daya tarik utama dari Desa Malatisuka yang menjadi ciri karena unik dan khas. Selain itu diperlukan pula terus adanya kajian dan usaha pembuatan inovasi untuk meningkatkan potensi ini dengan pelibatan seluruh pihak baik itu dari masayarakat, pelaku wisata sekitar, industri-industri yang terlibat, komunitas, media dan tentunya dukungan dari pemerintah.

2. Perlu adanya kajian, evaluasi dan sinergisasi seluruh pihak terkait untuk meningkatkan kembali aspek-aspek destinasi, pemasaran, industri dan kelembagaan dari kegiatan pariwisata kreatif di Desa Malatisuka ini, selain itu terdapat pula beberapa rekomendasi program pengembangan yang dapat dilakukan dengan rincian yang terdapat pada paparan sebelumnya.

3. Strategi pengembangan yang perlu untuk difokuskan adalah strategi diversifikasi. Perlu adanya program-program peragaman baik itu dari aspek destinasi, pemasaran dan industri yang terkait dalam kegiatan ekowisata di lingkungan Desa Malatisuka ini di dukung dengan peran dukungan dan dorongan dari kelembagaan (daerah dan pusat) sehingga lambat laun akan adanya perubahan dan kemajuan pesat sesuai dengan yang diharapkan.

\section{Daftar Pustaka}

Aliman, Muhammad. 2017. Pemanfaatan Media Sosial Dalam Ekowisata Air Terjun di Sumatera Barat (Sebuah Tinjauan Teoritis). Jurnal Spasial. Volume 4, Nomor 2. 
Fauziah Hanum, Reiza D. Dienaputra, Dadang Suganda, Budi Muljana

Badan Pusat Statistik Kabupaten Tasikmalaya, 2019. Kecamatan Gunung Tanjung Dalam Angka 2019.

Ballantyne, Roy \& Packer, Jan. 2013. International Handbook on Ecotourism. Edward Elgar Publisher.

Buckley, R., Pickering, C., \& Weaver, D.B. 2003. Nature Based Tourism, Environtment and Land Management. CABI Publishing.

Hidayat, Dian Charity \& Maryani, Retno. 2019. Analisis Kelayakan Potensi Ekowisata Air Terjun Riam Jito di Kecamatan Kembayan, Kabupaten Sanggau, Kalimantan Barat. Jurnal Penelitian Pengelolaan Daerah Aliran Sungai.

Jamil. Rima Sophal., \& Waluya, Bagja. 2016. Pengaruh Elemen Ekowisata Terhadap Keputusan Berkunjung Wisatawan Ke Taman Hutan Raya Ir. H. Djuanda. Jurnal Pendidikan Geografi. Volume 16, Nomor 01.

Kemendesa.go.id. 2019. Index Desa Membangun. Diakses dari: http://idm.kemendesa.go.id/idm_data?id_prov=32\&id_kabupaten=3206\&id_k ecamatan=320623\&id_desa=3206232007\&tahun=2019

Kementrian Pariwisata Republik Indonesia. Undang-Undang No 10 Tahun 2009 Tentang Kepariwisataan.

Murianto. 2014. Potensi dan Persepsi Masyarakat Serta Wisatawan Terhadap Pengembangan Ekowisata di Desa Aik Berik, Lombok Tengah. Jurnal Magister Pariwisata (JUMPA). Vol. 01, No. 01.

Putra, Adetiya Prananda. 2018. Pengaruh Tingkat Pendidikan dan Persepsi Terhadap Partisipasi Masyarakat Dalam Pengelolaan Daya Tarik Wisata Air Terjun Selendang Arum, Songgon - Banyuwangi. Jurnal Magister Pariwisata (JUMPA). Vol. 05, No. 03.

Samsuharjo., Margono, Subando Agus., \& Purbokusumo, Yuyun. Pengembangan Ekowisata di Air Terjun Sri Getuk. Academia.

Sunaryo, Bambang. 2013. Kebijakan Pembangunan Destinasi Pariwisata : Konsep dan Aplikasinya di Indonesia. Gava Media : Jakarta.

Suryajaya, I Putu Agus Mahendra \& Adikampana, I Made. 2019. Dampak Ekonomi Ekowisata Air Terjun Suranadi Terhadap Masyarakat Lokal di Jatiluwih. Jurnal Destinasi Pariwisata. Vol. 7, No. 2.

Ziku, Rafael Modestus. 2015. Partisipasi Masyarakat Desa Komodo Dalam Pengembangan Ekowisata di Pulau Komodo. Jurnal Magister Pariwisata (JUMPA). Vol. 02, No. 01. 


\section{Profil Penulis}

Fauziah Hanum, S.Par. Siswi Pascasarjana di Program Magister Pariwisata Berkelanjutan - Sekolah Pascasarjana Universitas Padjajaran yang aktif menulis dan menjadi asisten kegiatan penelitian dan kajian ilmiah. Bidang yang ditekuni yaitu smart tourism, sustainable tourism, agrotourism dan isu-isu sosial lainnya.

Prof. Dr. Reiza D. Dienaputra, M.Hum. merupakan seorang Guru Besar di bidang Ilmu Sejarah di Fakultas Ilmu Budaya - Universitas Padjadjaran yang aktif hingga saat ini. Bidang yang beliau tekuni yaitu analisis sejarah, kebudayaan dan tema-tema sosial masyarakat sebagai upaya pengembangan usaha yang berbasis lokal.

Prof. Dr. Dadang Suganda, M.Hum merupakan seorang Guru besar Fakultas Ilmu Budaya - Universitas Padjadjaran dan juga Wakil Rektor I (Bidang Akademik, Kemahasiswaan, dan Pembelajaran) di Universitas Widyatama yang masih aktif mengajar dan menulis hingga saat ini. Bidang yang beliau tekuni yaitu linguistik, pragmatik dan isu-isu sosial masyarakat.

Dr. Eng. Budi Muljana, S.T., M.T merupakan Ketua Program Studi Pasca Sarjana (Magister dan Doktor) Fakultas Teknik Geologi - Universitas Padjajaran yang aktif menulis hingga saat ini. Bidang yang beliau tekuni yaitu stratigrafi. 